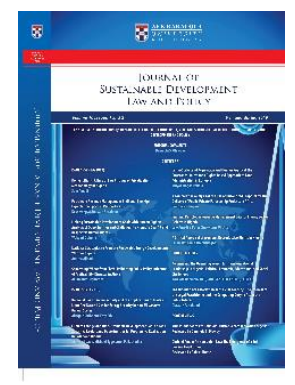

\title{
Designing Regulatory Governance Models for Managing Hydrocarbon Resources: Lessons Learned from Norway and the UK
}

\section{Eduardo G. Pereira, Eddy Wifa, Jonathon W. Moses}

To cite this article: Eduardo G. Pereira, Eddy Wifa \& Jonathon W. Moses (2020) Designing Regulatory Governance Models for Managing Hydrocarbon Resources: Lessons Learned from Norway and the UK, The Journal of Sustainable Development, Law and Policy, 11:2, 251-299.

To link to this article: https://dx.doi.org/10.4314/jsdlp.v11i2.1 


\title{
Designing Regulatory Governance Models for Managing Hydrocarbon Resources: Lessons Learned from Norway and the UK
}

\author{
Eduardo G. Pereira, ${ }^{*}$ Eddy Wifa, $* *$ Jonathon W. Moses***
}

(Received 07 October 2020; final version received 24 December 2020)

While the ever-evolving nature of the global energy industry remains apparent particularly with a transition away from fossil fuel energy systems, the role of oil and gas particularly for emerging economies is undeniable. As new discoveries of oil and gas emerge in countries in Africa, South America, and Southeast Asia, the dominant question will be how to design robust regulatory governance regimes not just for the exploration of oil and gas but also for the management of these resources. As both the United Kingdom and Norway are described as mature oil and gas jurisdictions by virtue of their profound experience, there are valuable lessons to be drawn. Despite some remarkable differences in both the UK and Norwegian regimes, experience suggests that strategy, foresight, regulatory rigour, and political will are valuable to mitigating the consequences of the political economy of speed, which suggest the development of natural resources at the expense of everything else. This paper provides both a comprehensive and critical appraisal of both the UK and Norwegian regimes in a way that captures the complexity of divergent regulatory governance structures.

Keywords: Resource Management, Regulatory Model, Hydrocarbon Regulations, Sovereign Wealth Fund, Fiscal Regime 


\section{INTRODUCTION ${ }^{1}$}

$\mathrm{T}$

he Norwegian resource management model is often considered a fairly "successful" example of how to manage hydrocarbon resources. ${ }^{2}$ The Norwegian government allowed a progressive development of its natural resources, built industry knowledge and saved reserves and revenue for future generations. This approach is often referred to as the Norwegian Model. ${ }^{3}$ The Norwegian hydrocarbon policies and the licensing regime are often cited as important factors contributing to the success of Norwegian resource management. However, other factors, such as the political system, demography, social issues, government structures, community support, naval traditions, amongst others, might also have played an important role. Norway and the United Kingdom (UK) started their North Sea exploration activities almost at the same time, and both countries adopted a licensing regime as a basis for resource management. Nevertheless, the Norwegian and the UK resource management models also differ in many respects.

The first and intermediate objectives of this article is to analyse the regulatory models for petroleum resource management, including the evolution of the license systems, in Norway and the UK as two neighbouring and mature petroleum provinces. This analysis aims to make a

* Dr. Eduardo G Pereira is a professor of natural resources and energy law in a full-time, part-time, associate, adjunct, research and/or visiting scholar in a number of leading academic institutions around the world (including the Siberian Federal University, University of São Paulo, University of Aberdeen, Strathmore University, Agostinho Neto University, Externado University of Colombia and among others). Further information about his profile and publications can be found at: www.eduardogpereira.com

$* *$ Dr. Eddy Wifa is an Energy and Natural Resource Law Lecturer at the University of Aberdeen, Scotland, United Kingdom.

$\because *$ Dr. Jonathon Moses is a professor at the Department of Sociology and Political Science, Norwegian

1 This Paper Is Based on the Book Eduardo G. Pereira, Henrik Bjornebye (Eds), Regulating Offshore Petroleum Resources: The British and Norwegian Models (Edward Elgar 2019).'

2 For further details see: Al-Kasim, Farouk (2006) Managing Petroleum Resources. The 'Norwegian Model' in a Broad Perspective. OIES 30 (Oxford: Oxford Institute for Energy Studies).

3 Ibid 
contribution to understanding the legal and policy consideration, as well as the economic history that underpins the regulatory approach adopted in the UK and Norway. Furthermore, an analysis of the regulatory models for petroleum resource management in two important and mature petroleum provinces should in itself be of interest for petroleum law practitioners and academics. While the "Norwegian Model" generally appears to be a popular example, and to some extent an inspiration, for the development of new resource management models in emerging petroleum provinces, it is our general impression that the British model has been less commonly referred to as an example for the establishment of new models in terms of resource management. This impression raises at least the following questions. First, to what extent are the Norwegian and British models being applied as examples or bases for the establishment of new petroleum resource management models within other jurisdictions? Second, to what extent are the Norwegian and British models suitable for replication within other jurisdictions and which precautions should be taken in replicating these models?

The two questions set out above raise challenges that go far beyond the area of law. This applies in particular to the second question, as the relevance of one resource management model for the construction of other models also will rely on a number of non-legal factors, such as economy, political system, demography, social, and cultural aspects, etc. This article proceeds in five main sections. Section one introduces the paper. Section two provides a factual and contextual background for the development of hydrocarbon policies for each jurisdiction. Section three endeavours to link the development of each legal regime to the factual background of each country. Section four provides a comparative legal analysis and as such answers the two questions above. Although the fluidity and legal nature of this paper make it almost impossible to provide a firm answer to all aspects of the questions, the legal and regulatory analysis sufficiently explores the main research questions. Section five covers the conclusions while the last section provides recommendations from this paper.

It is relevant to point out that in a continuously evolving global energy landscape and several pressures to meet energy 
expectation as well as climate changes affirmation actions, the discussion on how mature regimes have regulated oil and gas remain pertinent. The reason being that, not only would oil and gas continue to be relevant in a global stage (particularly in developing and less advanced jurisdictions), but those engaged in renewable energy might learn from the past mistakes from the hydrocarbon sector and avoid repeating similar mistakes.

Therefore, critical evaluation of resource management in mature oil and gas regimes like the UK and Norway would not only provide valuable lessons for the development of new hydrocarbon provinces like Guyana or Senegal but also for the development of other types of energy resources as part of resource management.

\section{HISTORICAL ANALYSIS OF OIL AND GAS DEVELOPMENT THE UNITED KINGDOM}

Oil discovery in the UK dates to the 1850s (shale oil) but it was not until 1919 that conventional oil was discovered albeit not in commercial quantities. ${ }^{4}$ Following the Second World War, Britain was compelled to search for alternative energy sources. It was not until the 1960s that there was some glimmer of hope and the search was intensified. ${ }^{5}$ In the 1970 s the search for oil in the UK had proved successful as commercially viable quantities of oil were discovered. ${ }^{6}$ This discovery was inspired by discoveries in the Dutch Groningen

${ }^{4}$ Alex Kemp, The Official History of North Sea Oil and Gas: The Growing Dominance of the State Vol 1 (Routledge 2012) page 7.

5 The National Archives "The Cabinet Papers" online a https://www. nationalarchives.gov.uk/cabinetpapers/themes/north-sea-oil-gas.htm accessed on the $25^{\text {th }}$ of October 2020.

6 Wesley G Carson The Other Price of Britain's Oil: Safety and Control in the North Sea (Martin Robertson Oxford 1982) 2 
oil fields. ${ }^{7}$ The Government passed the 1964 Continental Shelf Act in a bid to encourage the growth of the industry. ${ }^{8}$

The economic history within which the UK developed its oil and gas regime certainly provides some explanation to both its approach and to some extent, its successes especially as it relates to the resources curse debate. As Heffron et al. explain "The first trend began with the industrial revolution at the close of the eighteenth century, which transformed Britain's economy and society and made it the richest country in the world...

The country had the highest gross domestic product (GDP) per capita in the world". ${ }^{9}$ This was achieved by the use of new technologies and growth in industries like textiles, iron, and coal. By the late nineteenth to early twentieth centuries, Britain had lost its dominance in the global economy. ${ }^{10}$ Despite the economic and commercial impact of the First World War on European countries, which caused significant debt and inflation, the UK still enjoyed more economic advantage than most of its European counterparts like France and West Germany. ${ }^{11}$ Between 1960 and 1973, the United Kingdom had begun to experience significant economic challenges with inflation, devaluation, low employment and high national debts. The situation became particularly challenging as wages were capped. ${ }^{12}$ There were equally energy security concerns as the coal factories, which produced most of the energy were blocked as a result of a

7 Greg Gordon "Hydrocarbon Policies and Legislation: United Kingdom" in Eduardo G. Pereira and Henrik Bjornebye (eds), Regulating Offshore Petroleum Resources: The British and Nowegian Models (Edward Elgar 2019) 165-173.

8 Greg Gordon, Aileen Mcharg and John Paterson, "Energy Law in the UK”, in Martha Roggenkamp, Catherine Redgwell, Anita Ronne and Inigo Del Guayo, Energy Law in Europe, $\left(3^{\text {rd }}\right.$ ed Oxford University Press, 2016) at 14.11

9 Raphael Heffron, Mohammad Hazrati, Greg Gordon and Darren McCauley "Background United Kingdom" in Eduardo G Pereira and Henrik Bjornebye (eds), Regulating Offshore Petroleum Resources: The British and Norwegian Models (Edward Elgar 2019) page 129.

10 George Band "Fifty Years of UK Offshore Oil and Gas" (1991) Vol157

(2) The Geographical Journal 180.

11 Ibid 128-164.

12 Ibid. 
labour strike. These economic and energy security challenges explain the Government's enthusiasm to explore for oil.

In addition, other industries like shipping, shipbuilding, fisheries and services played an important role in the development of the oil and gas industry in the UK. Being an island nation, the shipping sector bloomed and it has significantly contributed to the UK economy since the 1870s. This was as a result of its "access to large markets which offered opportunities for mass production, specialization, cheap supply of raw materials and skilled men". ${ }^{13}$ The industry provided employment and a much-needed financial boost. It is estimated that in 2019 the industry contributed about £24billion to the UK's GDP while creating about 270,000 jobs. ${ }^{14}$ With the discovery of oil and gas, it is evident that such an industry must have played a pivotal role in the growth and development of the oil and gas industry.

Furthermore, it is relevant to point out that other crucial factors helped the UK at the beginning of its oil and gas developments: high level of education; highly sophisticated and longstanding legal system; fairly good standing with transparency and a low amount of corruption as well. ${ }^{15}$ These factors placed the UK in an advantageous position to develop its oil and gas resources.

The UK oil and gas industry has had a significant impact on the UK economy. Although such economic impact could easily be attributed to its sophisticated legal regime, it is hard to deny the role of its advanced infrastructure, diversified economy, and industry expertise. ${ }^{16}$ The UK remains the second-largest oil producer and the third gas producer in the Organisation for Economic Co-operation and Development (OECD) for the European continent. It was estimated that by 2017 more than 43 billion barrels had been recovered since commercial oil exploration began in 1967 and about $£ 330$

13 Ibid

14 Oil and Gas UK Economic Report 2019 online at https://oilandgasuk.co.uk/wp-content/uploads/2019/09/Economic-Report-2019 OGUK. pdf 6 accessed on the $25^{\text {th }}$ of October 2020.

15 Alex Kemp The Official History of North Sea Oil and Gas: Moderating the State's Role Voume II (2012 Routeledge).

16 Fred Atkinson and Stephen Hall, Oil and the British Economy Vol 6 (Routledge 2016) page 18. 
billion in corporate tax has been contributed to the Treasury. ${ }^{17}$ In 2018, the UK oil and gas industry contributed about 45 per cent to the country's energy needs. ${ }^{18}$ Despite the low investment climate within the industry, particularly owing to the downturn, it is difficult to ignore the contributions of oil and gas to the UK energy security and the economy in general.

\subsection{Norway}

There are significant similarities, but also some very important differences, separating the way that Norway and the UK approached the development of oil and gas in the mid-1960s. Primary among the differences was Norway's economic trajectory. While the UK was retreating from its imperial heights and could draw on a very long history of industrial development, Norway was slowly ascending the world's economic ladder and had not yet been seen as a particularly wealthy country, pre-oil. ${ }^{19}$ Neither was Norway poor: even though she was a very young country (gaining independence in 1905), she had developed a strong set of legal and political institutions; and she could draw from a highly trained and well-organized labour force -accustomed to adjusting rapidly to a changing global economy.

The engine of Norwegian economic development has always been fuelled by natural resources: fish, timber, ships, hydroelectric production (and the production of commodities that use cheap power) and now oil and gas. The industrialization of Norway was powered by huge hydroelectric installations, built at the very time Norway was wrestling its economic and political independence from Sweden. At that turn to the twentieth century, Norway

17 House of Commons Library "UK Offshore Oil and Gas Industry" (2017) Briefing paper CBP 07268 online at

18 Oil and Gas UK Economic Report 2019 online at https://oilandgasuk. co.uk/wp-content/uploads/2019/09/Economic-Report-2019-OGUK. pdf 6 accessed on the $25^{\text {th }}$ of October 2020.

19 To learn more about Norway's economic development before World War I, see Jonathon W. Moses (2005) Norwegian Catch-up: Development and Globalization before World War II (Aldershot, Hampshire: Ashgate, 2005). For a nice survey of more recent political and economic history in Norway, see Erik Jarlsby (2019) "Background: Norway," in Eduardo G. Pereira and Henrik Bjørnebye (eds) Regulating Offshore Petroleum Resources: The British and Norwegian Models (Cheltenham, UK: Edward Elgar): 6-38. 
developed a novel concessions system that limited foreign access to Norwegian waterfalls and ensured public control over common resources. She did so by securing a share of the value being produced at these hydroelectric installations, and by requiring that all capital investments (and the right of access) were returned to the state after an agreed-upon period of time (so-called hjemfall). This concessionary arrangement for the private exploitation of common resources -designed and built in the first two decades of the $20^{\text {th }}$ century - became the foundation for Norway's subsequent petroleum management regime, once oil was first discovered.

This was not pre-ordained. Unlike the UK, Norway did not have any previous experience with (shale) oil or gas on its sovereign territory. Before the late 1960s, Norwegian geological experts were convinced that there was no oil to be found in Norway - either onshore or of. Hence, the discovery of oil initiated an organizational scramble, as the Norwegian authorities considered how best to manage its new resource. After surveying the approaches of other oil countries, the needs of international oil companies, and its previous successes in managing its waterfall resources, the Norwegian authorities drew up a blueprint for how best to manage its petroleum resources, on behalf of the Norwegian people. The result was a novel institutional triad, where the need for autonomous policymaking, regulation and operational expertise was balanced against one another. ${ }^{20}$ The result is often referred to as the Norwegian model for petroleum management. ${ }^{21}$

In addition to its earlier experience in managing other natural resources (and foreign capital), Norway was able to draw on several local competencies that proved extremely beneficial, once oil production began offshore. In this way, Norway's experience was somewhat similar to the UK's. Norway's deep seafaring and boat-building traditions allowed the country to quickly fill the demand for new boats that could safely navigate the volatile North Sea region. After all,

20 Moses, Jonathon W. and Bjørn Letnes (2017) Managing Resource Abundance and Wealth: The Norwegian Experience (New York: Oxford University Press). Much of the Norwegian section of this article draws from this book.

21 Al-Kasim, Farouk (2006) Managing Petroleum Resources. The 'Norwegian Model' in a Broad Perspective. OIES 30 (Oxford: Oxford Institute for Energy Studies). 
the first generation of supply boats, and the first drilling rigs, were dragged over from the Gulf of Mexico, and their shortcomings were almost immediately obvious-the conditions in the North Sea are much more challenging than those found in the Gulf. Norway's experience with massive dam-building projects had created highly competent concrete and engineering facilities - and this domestic expertise became instrumental when the offshore industry needed enormous undersea bunkers made of concrete (e.g. the Ekofisk tank), and turned to gigantic production platforms built of concrete (e.g. of the Condeep type, ala Troll). Norway's engineering schools, and its related industrial base, were already geared to providing these sorts of competencies before oil was found, and were quickly drafted into service, once viable wells were discovered.

As in the UK, the resulting oil and gas industry has had an enormous and lasting impact on the Norwegian economy. Today, Norway produces about three per cent of global demand and is the third-largest exporter of natural gas (following Russia and Qatar)..22 Norwegian gas supplies roughly a quarter of the EU's current gas demand. ${ }^{23} \mathrm{It}$ is most common to point to Norway's phenomenal wealth, collected in the world's largest sovereign wealth fund: the Government Pension Fund Global (GPFG). ${ }^{24}$ A half-century of petroleum production, under some of the world's most challenging conditions (deep water, hazardous surface conditions, challenging weather), has also resulted in the development of world-class expertise in Norwegian engineering, production, and supply industries. Today, the oil and gas sector is Norway's largest, when measured in terms of value-added, government revenues, investments and export value. While the 2020 figures are smaller than in years past, the oil and gas sector captures about 10 per cent of Norway's GDP and state

22 Norwegian Petroleum (2020) “Exports of Oil and Gas." 29 June 2020 draft. Online at https://www.norskpetroleum.no/en/production-andexports/exports-of-oil-and-gas/. Accessed on the $30^{\text {th }}$ of September 2020. Norwegian Petroleum (www.norskpetroleum.no) is an information website run by the MPE and NPD.

23 Ibid.

24 Norges Bank Investment Management (2020) “The Fund." Online at https://www.nbim.no/en/. Accessed on 30 of September 2020. 
revenues, roughly 30 per cent of its export value $e^{25}$ and perhaps five per cent of Norwegian employment. ${ }^{26}$

\section{REGULATING OIL AND GAS EXPLORATION}

\subsection{The United Kingdom Continental Shelf}

The regulation and management of the UK oil and gas industry following the First World War began with the promulgation of the Petroleum (Production) Act 1918. ${ }^{27}$ The key issue at the time was ownership of the oil and gas industry, unfortunately, the Act did not resolve this. The issue of ownership remained unresolved and the unsuccessful attempts of state-funded drilling activities meant that the oil and gas industry under the 1918 Act did not develop as it should have. ${ }^{28}$ Also, the fact that the importation of oil was provided at a very reasonable cost meant that there was very little motivation to spend so many resources exploring for oil. ${ }^{29}$

In 1934, The Petroleum (Production) Act was promulgated to encourage the growth of the industry and it was a piece of legislation that significantly changed the nature of oil and gas operations in the UK particularly as it relates to

25 Norwegian Petroleum (2020) “The Government's Revenues.” 12 May 2020 version. Online at https://www.norskpetroleum.no/en/economy/governments-revenues/. Accessed on the 26th of September 2020.

26 Statistics Norway (2019) "Ringvirkninger av petroleumsnæringen inorsk økonomi.” Report 2019/37. Online at: https://www.ssb.no/na sjonalregnskap-og-konjunkturer/artikler-ogpublikasjoner/attachment/405655?_ts=16ecb1da138 Accessed on the 30 ${ }^{\text {th }}$ of September 2020.

27 For detailed discussion of the UK oil and gas regulatory regime, see Greg Gordon, John Paterson and Emre Usenmez "UK oil and Gas Law: Current Practice and Emerging Trends Vol1 ( $3^{\text {rd }}$ Edition Edin-burgh University Press 2018).

28 Greg Gordon, "Hydrocarbon Policies and Legislation: United Kingdom" in Eduardo G. Pereira and Henrik Bjornebye (eds), Regulating Offshore Petroleum Resources: The British and Nowegian Models (Edward Elgar 2019) pages 165-210.

29 Ibid. 
licenses. ${ }^{30}$ The Act in resolving the ownership controversy vested in the Crown 'property in petroleum, existing in its natural condition in strata in Great Britain' 31 and 'granted it exclusive right to search and bore for and get such petroleum'..$^{22}$ Owing to the power, the Crown exercised this right by granting licenses in exchange for royalties and taxes. ${ }^{33}$ The 1934 Act did not contain any penalties for a breach in the licences. One argument for this amongst others could be to encourage investment and foster the growth of the industry. ${ }^{34}$ From an onshore perspective, the principles in the 1934 Act are replicated in the 1998 Petroleum Act save for some amendments.

With less encouraging oil and gas development onshore and encouraged by discoveries in Netherland and Norwegian Continental Shelf in the 1950s and 1960s respectively, the UK intensified efforts to exploit for oil and gas offshore. ${ }^{35}$ Therefore, without very much thought of an alternative or the differences and similarities between onshore and offshore regimes, ${ }^{36}$ it exported its "existing and largely untested landward licensing regime" offshore. ${ }^{37}$

To encourage exploration of its oil and gas resources at a time when the UK was in grave economic difficulties, the Continental Shelf Act of 1964 was enacted and Section 1(1) vested in the Crown "any rights exercised by the United Kingdom outside territorial waters concerning the sea-bed and subsoil and their natural resources", except coal, which

30 Greg Gordon, "Production Licensing on the UK Continental Shelf: Miniterial Powers and Controls" (2015) 4(1) LSU Journal pf Energy and Natural Resources 75.

31 Section 1(1) Petroleum (Production) Act 1934 fundamentally.

32 Ibid.

33 Mary Sabina Peters and Manu Kumar, "Unique UK's Licensing Favours the State than the Industry: Contradicting Conventionsl Wisdom" (2013) 54 (2) Acta Juridica Hungarica 204

34 Ibid.

35 Greg Gordon, "Hydrocarbon Policies and Legislation: United Kingdom " in Eduardo G. Pereira and Henrik Bjornebye (eds), Regulating Offshore Petroleum Resources: The British and Nowegian Models (Edward Elgar 2019) pages 170-210.

36 Alex Kemp "Official History of North Sea Oil Vol 1: The Growing Influence of the State (Routledge 2012) page 9.

37 Ibid. 
was vested in the National Coal Board. ${ }^{38}$ With a somewhat skeletal regime in place, the priority was to explore for oil and reap the benefits. This was evidenced in the perhaps "broad discretionary powers of the Secretary of State and leaving the fine detail of the relationship between the state and the licensee to the Model Clauses and the terms of the individual licence". ${ }^{39}$ It must be noted that the unique nature of the UK licensing regime meant that it was not a lease and the state contrary to the position onshore, the state does not purport to own the continental shelf or the oil and gas in the strata beneath it but only exercises "sovereign rights". Therefore in exercising such right the Crown simply authorises an activity, which would have been otherwise considered unlawful. ${ }^{40}$ In doing so, the license in both its regulatory and contractual nature transmits the ownership of the hydrocarbon upon exploration to the licensee. This to a very large extent limited the role of state participation or control.

With full implementation of what seemed like a fairly effective oil and gas regime, the expectation was that Britain would opt for majority participation through the establishment of a national oil company. This led the then Labour Government to enact the Petroleum and Submarine Pipelines Act of 1975, which essentially related to the ownership of production. The Labour government argued that if elected, it would:

Take majority participation in all future oil licenses and negotiate to achieve majority state participation in existing licences. Set up a British National Oil Corporation to enable the Government to exercise participation rights; to play an active role in future developments, exploration and exploitation of

38 S 1 (2) Continental Shelf Act.

39 Greg Gordon, "Production Licencing on the UK Continental Shelf: Ministerial Powers and Controls', (2015) 4 LSU Journal of Energy Law and Resources, pp75-95.

40 Greg Gordon "Petroleum Licensing” in Greg Gordon, John Patersonand Emre Usenmez (eds.) UK Oil and Gas Law: Current Practice and Emerging Trends (Resource Management and Regulatory Law) (Edinburg University Press 2018) 84. 
offshore oil; and to engage in the refining and the distribution of oil. ${ }^{41}$

While some temporary successes were achieved in the formation of British National Oil Company by the Labour government, it was not very long after that the Conservative government subsequently decided to privatise both the British National Oil Company and the British Gas Corporation. ${ }^{42}$ The Conservative Party based its decision on the general move against state ownership of (generally profitable) assets, which were capable of being managed by the private sector and to improve energy efficiency. However it is viewed, it is hard to ignore the influence of political ideologies on the regulation and management of the British oil and gas regime. In some ways, such political influences could be responsible for the lack of strategic foresight and inconsistencies (especially in the governmental participation and tax regime). ${ }^{43}$ These concerns are certainly responsible for the current state of the industry. Regarding local content and state participation, the UK took a slightly concerning approach particularly in the context of the oil and gas industry. While acknowledging the relevance of local content regulation and policies in the development of an industry and an opportunity to maximise economic recovery, its application varies from state to state. While some jurisdictions have clearly defined minimum local content requirement, others have a more flexible approach. It is difficult to say, which is more effective as the robustness of the local content regime, is largely dependent on factors beyond the regulatory design. Although, there have been attempts to develop local content through direct state participation in the

${ }^{41}$ Philp Wright and Juan Carlos Boue "The United Kingdom: Public Debate and the Management of Petroleum Resources" in IndraOverland (eds) Public Brainpower: Civil Society and Natural Resources Management (Palgrave Macmillian 2018) 331.

42 Stephanie Hoopes "The Privatization of UK Oil Assets 1977-87: Rationa -1 Policy Making, International Changes and Domestic Constraints” (1994) A PhD thesis submitted to the Department of Government of International Relations, London school of Economics.

43 Greg Gordon "Petroleum Licensing" in Greg Gordon, John Paterson and Emre Usenmez (eds.) UK Oil and Gas Law: Current Practice and Emerging Trends (Resource Management and Regulatory Law) (Edinburg University Press 2018) 84. 
early years of the North Sea development along with incentives to increase higher participation of the local supply chain, in more recent times it has become apparent that there was no explicit and specific local content regime in the UK offshore oil and gas industry as it is commonly provided in other jurisdictions. ${ }^{44}$ This is not to say there are no efforts to develop the supply chain especially through efforts like the Offshore Supply Office and the Maximisation of Economic Recovery (MER) Strategy, ${ }^{45}$ but nothing like the traditional local content regimes that can be found be found in other oil and gas jurisdictions. The closest the UK got to a local content policy was back in the 1970s when the 'full and fair opportunity' principle was included the Department of Energy's licence allocation procedure. ${ }^{46}$ This principle required the licence applications to be determined based on the applicant's ability to guarantee the full and fair opportunity to UK industries. ${ }^{47}$ Not very much success was recorded in terms of significant local content development and the policy was eventually discontinued because it was discriminatory and protectionist vis-à-vis its community agreements in the EU. ${ }^{48}$

\subsection{Regulating Oil and Gas Exploration in Norway}

In many ways, the nature of Norway's regulatory regime could not be more different than the British one just

${ }^{44}$ Greg Gordon "Hydrocarbon Policies and Legislation: United Kingdom " in Eduardo G. Pereira and Henrik Bjornebye (eds), Regulating Offshore Petroleum Resources: The British and Nowegian Models (Edward Elgar 2019) 165-173

45 Department for Business, Energy \& Industrial Strategy (DBEIS) Maximising Economic Recovery Strategy for the UK (2016) < https://www.gov.uk/government/publications/maximising-economicrecovery-of-uk-petroleum-the-draft-mer-uk-strategy $>$ accessed on the $25^{\text {th }}$ of October 2020.

46 Greg Gordon "Hydrocarbon Policies and Legislation: United Kingdo$\mathrm{m}$ " in Eduardo G. Pereira and Henrik Bjornebye (eds), Regulating Offshore Petroleum Resources: The British and Nowegian Models (Edward Elgar 2019) 165-173

47 London Gazette, Issue 47612, 8 August 1978, p9508, para 5.

48 Alex Kemp, The Official History of North Sea Oil and Gas: The Growing Dominance of the State Vol 1 (Routledge 2012) page 7. 
described. ${ }^{49}$ These differences probably reflect the very different times and contexts in which issues of ownership and control were being discussed in the two countries. For the United Kingdom, many of the most important issues of ownership and control were being settled in the interwar period, whereas Norway only began to address them in the 1970 s - in a global context where national control of natural resources was on the rise.

In Norway, public ownership and control of these offshore natural resources were never in doubt. ${ }^{50}$ What most worried the Norwegian authorities was the question of how far that Norwegian ownership and control extended beyond Norway's coastline. For that reason, the very first political issue to be determined was the exact location of the territorial boundaries that separated Norway from her neighbours. In particular, before Norway began developing its regulatory regime, it first negotiated the limits to its territorial boundaries with both the UK and Denmark - to ensure that it had

${ }^{49}$ For a general introduction to Norway's petroleum management regi-me, see Moses and Letnes, Managing Resource Abundance. For a mo-re focused survey of Norway's hydrocarbon policies and legislation, see Tonje Pareli Gormley and Merete Kristensen (2019)"Hydrocarbon policy and legislation: Norway,” in Eduardo G. Pereira and Henrik Bjørnebye (eds) Regulating Offshore Petroleum Resources: The British and Norwegian Models (Cheltenham, UK: Edward Elgar): 39-95.

For example, in 2011, the Norwegian government described its relation-ship to petroleum resources thus: “Norway's petroleum resources belong to the Norwegian people, and they must be managed in a way that benefits the entire Norwegian society. This has been the foundation for the management of our petroleum resources for the past 50 years. The licensing legislation dating back to 1909 deals with regulation of hydropower, but it has also been relevant for the petroleum activities. The legislation stipulated the right of reversion (to the State), emphasised that the Norwegian people are the owners of the water resources, and that economic rent should fall to the greater community. These same principles have been followed in the administration of the petroleum resources.” From Meld. St. 28 (2010 - 2011) «En næring for framtida om petroleumsvirksomheten. En næring for framtida - om petroleumsvirksomheten.» Tilråding fra Olje- og energidepartementet av 24. juni 2011, godkjent i statsråd samme dag. (Stoltenberg II Government). Unofficial translation from https://www.regjeringen.no/globalassets/upload/oed/petroleumsmeldi ngen_2011/oversettelse/chapter1_white_paper_28-2010-2011.pdf, acessed on the $30^{\text {th }}$ of September 2020. 
sovereign control over that territory. By May of 1963, Norway’s Prime Minister, Einar Gerhardsen, could proclaim sovereignty over the Norwegian Continental Shelf. ${ }^{51}$ In hindsight, this effort to secure the boundaries, before any petroleum assets were found on the territory, proved very fruitful, as much of Norway's subsequent petroleum activity occurred around the border territory shared by Norway, Denmark, and the UK.

Once Norway secured an agreement with her neighbours about the boundaries of her sovereign control, she could begin to establish a licensing regime for the eventual exploration and production. At the time (the early-1960s), there was hardly any interest in Norway's offshore territory: most international attention was being focused on the other countries surrounding the North Sea rim: especially the Netherlands and the UK. Norway was the odd one out, and only one company - Phillips Petroleum - seemed to be interested in exploring Norwegian territory. It was, indeed, Phillip's stubborn persistence to secure the rights to exploration in Norway that eventually pushed the Norwegian authorities into action. Given the absence of international interest at the time, it was probably not so remarkable that Phillips' original request (October 1962) asked for the exclusive rights to all petroleum on Norwegian territory (at the bargain price of just $\$ 160,000$ a month). ${ }^{52}$ With hindsight, however, we can see it was a remarkably bold bid!

Fearing a drought of interested parties, the first allocation of Norwegian licenses was unusually liberal. A huge section of the Norwegian continental shelf was put on the market (the largest ever in Norwegian history), and the terms of the resulting licenses were incredibly generous. ${ }^{53}$ The initial intent was to try and attract as much of the international expertise as was needed, and Norway did this by offering extremely favourable terms. Remember, Norway was competing

51 Norwegian Government (2013) "Norway's oil history in 5 minutes." Online at https://www.regjeringen.no/en/topics/energy/oil-and-gas/norways-oil-history-in-5-minutes/id440538/. Accessed on the $30^{\text {th }}$ of September 2020.

52 Ibid.

53 The first allocation round was announced on 13 April 1965, and resulted in 22 production licenses, covering a total of 78 blocks. These production licenses granted exclusive rights for exploring, drilling and production in the licensed areas. 
directly with the UK at this time, to secure the international expertise, capital and interest that was circulating in the North Sea - as the world began searching frantically for more reliable sources of energy (i.e., beyond the Middle East). Worse, Norway was saddled with two distinct disadvantages in this competition (from the perspective of international investors): a lack of faith that the resources were to be found under Norwegian waters, and Norway's socialist history and reputation.

Norway was extremely lucky in that this initial activity (during the first allocation round) was mostly unsuccessful. By the end of the first round, in 1969, interest in the Norwegian fields was declining, and companies were beginning to withdraw their activities from the Norwegian shelf. It was only with the surprise discovery at Ekofisk, in December 1969, that interest in the Norwegian field was again buoyed. In discovering a huge new field of activity, Norway's attractiveness as a petroleum destination changed overnight: Norway was now in the driver's seat and changed the nature of the consequent contract terms as a result (to the evident disgust of international oil companies).

The management regime that developed with (and after) this second allocation round (1969-1971), allowed for significant national control and ownership over, and benefit from, Norwegian petroleum resources. This scope for political autonomy was larger in the 1970s than it was in the interwar period (when the UK was developing its regime), and it was much greater than we find in the world today. After all, OPEC was created in September 1960, and in 1962, the UN General Assembly adopted its "UN Resolution on Permanent Sovereignty over Natural Resources." ${ }^{.54}$ In a broader context, the 1970s was a time when the international community was considering a New International Economic Order, and democratic pressures and protests were springing forth around the world.

Unlike the UK, Norway took advantage of this scope for autonomous policy and developed a regime that secured

54 UN General Assembly (1962) "UN Resolution on Permanent Sovereignty over Natural Resources.” Online at http://legal.un.org/avl/ha/ga1803/ga_1803.html. Accessed on the 30 of September 2020. 
strong democratic control over the resource (and its rents). This control is most evident in Norway's famed " 10 Oil Commandments", which provided the political guidelines for subsequent development. ${ }^{55}$ The nature of the resulting licensing regime ${ }^{56}$ allowed Norway to control the pace of development on the Norwegian Continental Shelf (NCS), promote the development of Norwegian competence and ensure that a broader Norwegian competence was tapped and encouraged. The results of this control can be seen on several fronts, including the establishment of a competent and powerful NOC (Statoil, now Equinor), vibrant domestic supply industry and the development of sophisticated technical expertise - both in the research community and in the industry more generally. Much of this activity has subsequently graduated from the NCS to become competitive in the global economy. At the same time, the nature of this regime allowed the Norwegian people to secure enormous wealth, in the form of the returns from shared licenses (socalled State's Direct Financial Interest, or SDFI), and the phenomenal growth of the GPFG.

\section{LESSONS LEARNT}

This section is divided into three parts. Firstly it deals with lessons from the UK. Secondly, it deals with lessons from Norway. In each of these parts, the UK and Norwegian lessons are organised under four rubrics: a) political and fiscal (in)stability and long term perspectives; b) health, safety and environmental regulatory challenges; c) challenges in regulating third-party access to infrastructure; and d) offshore decommissioning. Thirdly it highlights the key common areas and distinctions from both experiences.

\subsection{The UK experience}

55 For an English translation of the 10 Oil Commandments, see Moses and Letnes, Managing Resource Abundance, p.74.

56 For a detailed study of Norway's current licensing regime, see Henrik Bjørnebye and Catherine Banet (2019) “Licensing Regime: Norway," in Eduardo G. Pereira and Henrik Bjørnebye (eds) Regulating Off-shore Petroleum Resources: The British and Norwegian Models (Cheltenham, UK: Edward Elgar): 96-127. 


\subsubsection{Political and Fiscal Instability and Lack of Long-Term Perspectives}

Despite the recorded successes of the UK oil and gas industry, it is important to identify some challenges that were experienced. Of particular relevance, is the Political Economy of Speed. ${ }^{57}$ This is the perhaps understandable haste of a Government upon the discovery of oil and gas to prioritise its exploitation at the expense of both strategic thinking and the needed regulatory interventions. While such haste is understandable in the interim, the challenges are long-lasting and, in some cases, irreversible. The impact of a political economy of speed in the development of the UK oil and gas sector is evidence in its somewhat ad hoc licensing regime, relative lack of strategic planning and state direction and the non-interventionist governance approach where the State played a less pronounced policy role. ${ }^{58}$ Perhaps it is in this regard that Gordon criticised the early licencing and governance regime as being "insufficiently sophisticated to properly protect the State's Interest" ${ }^{59}$ Further evidenced by the fact that licences were given with long terms, minimal relinquishment requirements and limited powers on the State to direct or influence the pace of operations". ${ }^{60}$ This led to a weakness in the fiscal regime, which meant that it was "possible for a licensee to manipulate its affairs to artificially create a situation where no tax was payable relative to its upstream operations". ${ }^{61}$ While this problem was later resolved

\footnotetext{
57 Wesley. G Carson “The Other Price of Britain’s Oil: Safety and Control in the North Sea” (Martin Robertson 1981) page 84

58 Greg Gordon "Hydrocarbon Policies and Legislation: United Kingdom ” in Eduardo G. Pereira and Henrik Bjornebye (eds), Regulating Offshore Petroleum Resources: The British and Nowegian Models (Edward Elgar 2019) pages 165 -210.

59 Greg Gordon "Petroleum Licensing” in Greg Gordon, John Paterson and Emre Usenmez "UK oil and Gas Law: Current Practice and Emerging Trends Vol1 ( $3^{\text {rd }}$ Edition Edinburgh University Press 2018) page 81.

60 Greg Gordon "Hydrocarbon Policies and Legislation: United Kingdom" in Eduardo G. Pereira and Henrik Bjornebye (eds), Regulating Offshore Petroleum Resources: The British and Nowegian Models (Edward Elgar 2019) pages 165- 210.

61 Ibid 170.
} 
through several regulatory interventions, which also contributed for the well-known instability of the UK oil and gas tax regime, other challenges like the regulations of health, safety and environmental and the question of a sovereign Wealth Fund were identified. ${ }^{62}$

Also, it is outside the scope of this article to deal with the complex fiscal system in the UK and its evolution throughout time. ${ }^{63}$ However, it is possible to highlight that the UK changed its fiscal system several times throughout the past decades. Quite often in favour of the Government. ${ }^{6465}$ For example, as the UKCS became closer to its maturity the UK Government realize that certain measures should be taken to ease the fiscal arrangement to maintain a higher level of investment, such as the abolishment of royalties. ${ }^{66}$ It is interesting to mention that the UK fiscal system never captures a bonus requirement as the main focus was towards exploration and production activities. ${ }^{67}$ The lack of stability in the fiscal system may have caused a significant impact on the way investors foresee the confidence and return of their investments.

The above theory of the political economy of speed and the UK's lack of strategic long term vision on the management of the proceeds of its oil and gas informed the reluctance to establish a Sovereign Wealth Fund, unlike her Norwegian counterpart. This is despite several parliamentary debates on the need to establish one. ${ }^{68}$ Informed by the UK leaving the European Union, a most recent debate on the need to create an SWF was sponsored by John Penrose:

\footnotetext{
22 Ibid.

Ibid.

${ }^{4}$ Ibid.

65 Ibid.

66 Ibid.

67 Ibid.

68 House of Commons Library "UK Soveriegn ealth Fund" (2016) Debate Pack Number CDP 2016/0243 online at file://C:/Users/s06ew9/Des-ktop/CDP-2016-0243.pdf > accessed on the 27th of February 2020.
} 
"We are historically worse at long-term planning than many other developed nations: ... Other oilrich countries like Norway have built up large sovereign wealth funds, but we have not. Can we resolve this weakness using the spur of our newly found freedoms to change the way we work once separation from the EU is complete"

Penrose's expectation that having a SWF could make UK the strongest economy in the G20 makes an argument that if established in the early years of oil and gas explorations, perhaps there would have been significant benefits. Despite the apparent benefits of a SWF, the response by Simon Kirby from Her Majesty's Treasury seemed to suggest that a SWF was not one of the government's priorities. Despite the arguments of Penrose MP for a SWF in the UK, the UK government remains less willing to establish one.

In the absence of a SWF from oil and gas revenue, there were several consultations and perhaps some willingness on the part of the government to establish one for shale gas extraction. ${ }^{70}$ The fund was designed to "consist of up 10 per cent of tax from shale gas production, to be used for the benefit of communities which host shale sites". ${ }^{71}$ During the consultation for a Shale Wealth Fund, the government argued that:

"The local people should have greater control and say in decisions that affect them. More than this, we are committed to delivering an economy that works for everyone, through ensuring that the benefits of economic growth and investment are spread as

${ }^{69}$ John Penrose MP “The Great Rebalancing: A Sovereign Wealth Fund to make the UK's Economy the Strongest in the G20" (2016) online at http://www.smf.co.uk/publications/the-great-rebalancing-a-sovereign wealth-fund-to-make-the-uks-economy-the-strongest-in-the-g20/ accessed on the $27^{\text {th }}$ February 2020.

70 Her Majesty's Treasury "Shale Wealth Fund: Response to the Consultation" (2017) online at <https://assets.publishing.service.gov.uk/government/uploads/system/uploads/attachment_data/file/658793/shale --wealth_fund_response_web.pdf $>$ accessed on the 27th of February 2020.

71 Ibid. 
widely as possible. This is why we are creating a Shale Wealth Fund, which could deliver up to $\mathfrak{E} 1$ billion of funding and will ensure that the benefits of shale developments are directed to the communities that host them "12

In what appeared to be a test run, independently, companies decided to make payments to host communities, perhaps as a sign of goodwill following the community engagement charter that was published by the UK onshore Oil and Gas (UK OOG). Following the commencement of exploratory drilling at Preston, Lancashire, $£ 100,000$ was paid by Caudrilla to an independent Community Benefit Fund. ${ }^{73}$ In fact, 80 per cent of the local residents indicated that rather than invest in different community projects, they would prefer direct payments to households within $1.5 \mathrm{~km}$ of the site. ${ }^{74}$ With increasing uncertainties over the future of the UK shale gas industry particularly owing to the realisation that risks could potentially outweigh any meaningful benefit ${ }^{75}$ and the enthusiasm to explore cleaner energy sources, it can be argued the Shale Wealth Fund is moribund.

\subsubsection{Health, Safety and Environmental Regulatory Challenges}

From a Health and Safety risk governance perspective, the UKCS has had its share of regulatory challenges as it appeared to be experimenting with different regulatory methods. It is important to note that regulating the offshore oil and gas industry in the United Kingdom, and indeed other parts of the world, is quite a challenging task. This challenge is not only as a result of the uncertain and hazardous nature of the offshore environment but also due to evolving technology. The situation is complicated further by the constant tension between HSE (Health, Safety and Environment) and cost especially as energy companies are under pressure to meet

72 Ibid.

73 Ibid.

74 Ibid.

75 UK Parliament "Energy Policy Update"(2019) online at <https://www.parliament.uk/business/publications/written-questions-answers statements/written-statement/Commons/2019-1104/HCWS68/>acess ed on the $27^{\text {th }}$ of February 2020. 
deadlines and deliver various forms of energy with the lowest possible financial implication. ${ }^{76}$ Unfortunately, this tension, in most cases, is resolved in favour of cost especially as energy operators and contractors are enthusiastic in their quest to maximise profit and are therefore unable to find the appropriate balance. ${ }^{77}$ This challenge appears to be one of the reasons behind some of the offshore safety disasters that have befallen the oil and gas industry and the UK has had its share of these experiences. Having experimented with several offshore safety regulatory regimes, in the aftermath of the Piper Alpha disaster where 168 men were killed, the UK made significant regulatory changes and settled for the Safety Case/Goal Setting approach. This section suggests that there are significant lessons to be drawn from the UK offshore oil and gas experience in this regard. One such lesson is the adoption of a safety case regulatory model that is most suitable for regulating health and safety risks in a complex and unpredictable offshore energy environment. ${ }^{78}$

The United Kingdom's Continental Shelf (UKCS) is popularly referred to as a mature province owing to the growth of its oil and gas exploration, likewise its offshore health and safety regime. ${ }^{79}$ Unfortunately, most of these were reactive and only occurred owing to offshore health and safety challenges such as accidents. These offshore health and safety challenges and accidents are reflected in the regulatory architecture - from Defacto-Self regulation under the licensing regime to a prescriptive regulatory regime with multiple laws

76 John Paterson, 'Health and Safety on the UK Continental Shelf' in Preben H Lindoe, Michael Baram and Ortwin Renn (eds), Risk Governance of Offshore Oil and Gas Operations (Cambridge University Press 2014) 132.

77 Steve Tomb and Dave Whyte, 'Capital Fights Back: Risk, Regulation and Profit in the UK Offshore Oil

78 The Safety Case regulatory model is one that requires the operator demonstrate measures taken to mitigate health and safety risks to a level that is as low as reasonably practicable (ALARP). For more on the UK Safety Case Model see John Paterson, 'Health and Safety Regulation on the UK Continental Shelf: Evolution and Future Prospects' in Preben Lindoe, Michael Baram and Ortwin Renn (eds), Risk Governance of Offshore Oil and Gas Operations (2014 CUP) 132.

79 Eddy Wifa "The Offshore Oil and Gas Safety Case Regulatory Model: Is it Worth the Hype?” (2018) 36 International Energy Law Review 206. 
and finally the 'fit for purpose' safety case, goal-setting regime. ${ }^{80}$

Having adopted the safety case regulatory model and being apparently satisfied with the approach, in 2010, the suitability of this approach was questioned, especially in the aftermath of the 2010 Macondo disaster in the Gulf of Mexico and the passing of the EU Offshore Safety Directive. The UK has had to once again restructure its offshore health and safety regulatory landscape. ${ }^{81}$ While there is some confidence in the safety case regime, UK offshore oil and gas safety regulatory architecture will continue to be tested especially with decommissioning and new discoveries further offshore.

Although the UK government appeared somewhat content with its Safety Case regime as a sophisticated model in the regulation of offshore health and safety risks, from an environmental perspective, things did not look particularly fit for purpose. The environmental regime at some point could be characterised as prescriptive and although the issue of potential conflict of interest had been resolved in relation to health and safety, ${ }^{82}$ it remained unresolved with regards to environmental regulation. This was particularly evident following the Macondo disaster and the promulgation of the EU Offshore Safety Directive, which amongst other provisions, was concerned with resolving the issue of potential conflict of interest. In this regard, paragraph 20 provided in ensuring:

"the independence and objectivity of the regulator ... the organisation of administrative competencies within a member state can prevent conflict of interest by a clear separation between regulatory

80 John Paterson, 'Health and Safety at Work Offshore' in G Gordon, J Patterson and E Usenmez (eds), Oil and Gas Law-Current Practice and Emerging Trends ( $3^{\text {rd }}$ Edition Edinburgh University Press 2018) 284.

81 John Paterson, 'Health and Safety on the UK Continental Shelf' in Preben H Lindoe, Michael Baram and Ortwin Renn (eds), Risk Governance of Offshore Oil and Gas Operations (Cambridge University Press 2014) 132.

82 Following the Piper Alpha disaster and the Cullen Report, the Health and Safety Executive was made responsible for health and safety and had no economic or licensing responsibility. See Eddy Wifa "The Offshore Oil and Gas Safety Case Regulatory Model: Is it Worth the Hype?” (2018) 36 International Energy Law Review 206. 
functions and associated decisions relating to offshore safety and environment and to the regulatory function relating to the economic development of offshore natural resources including licensing and revenues management. Such conflicts of interest are best prevented by complete separation of the competent authority from the functions relating to the economic development of offshore natural resources. $\$$

While the issue of potential conflicts of interest in relation to the UK's health and safety regulatory regime was resolved post-Piper-Alpha, the potential for such conflicts of interest regarding environmental matters remained unresolved. For this reason, Tromans and Norris, therefore, argued that it is 'questionable whether the United Kingdom regime is immune from the criticisms levelled against the MMS' before the Macondo incident. ${ }^{84}$ This is because the DECC, now the Department for Business, Energy and Industrial Strategy (BEIS), as it was known at the time, remained the competent regulatory body for ensuring compliance with environmental regulation and also the issuance of production licences. ${ }^{85}$

However, following the 2013 European Directive, and the need for the Member States to comply with its requirements, the UK enacted the Offshore Installations (Offshore Safety Directive) (Safety Case etc) Regulations 2015 and it also set up a new competent authority known as the Offshore Safety Directive Regulator (OSDR) as a department of the Health and Safety Executive. ${ }^{86}$ The Offshore Safety Directive

83 Directive on Health and Safety Offshore <http://ec.europa.eu/energy/oil/offshore/standards_en.htm $>$ accessed on the $13^{\text {th }}$ of October 2020.

84 Stephen Tromans and Josephine Norris, 'What if Deepwater Horizon Occurred West of Shetland' (2010) International Energy Law Review 220.

85 Luke Havemann and Tina Hunter, 'Environmental Law and Regulations on the UKCS, in Greg Gordon, John Paterson and Emre Usenmez (eds), Oil and Gas Law-Current Practice and Emerging Trends: Resource Management and Regulatory Law ( $3^{\text {rd }}$ Edition Edinburgh University Press 2018) 340.

${ }^{86}$ HSE Offshore Safety Directive Regulator <http://www.hse.gov.uk/osdr/authority/index.htm> accessed on the $19^{\text {th }}$ of October 2020. 
Regulator is an independent body made up of members of both the BEIS and the HSE with a senior oversight board. ${ }^{87}$ The OSDR is the competent authority tasked with 'overseeing industry compliance with EU Directive on the safety of offshore oil and gas operations' ${ }^{88}$ This includes approval of Major Hazard Report (MHR), carrying out routine inspections, investigation of incidents as well as the power to prohibit operations where it is of the 'opinion that the measures for preventing or limiting the consequence of a major accident proposed in the safety case are insufficient' ${ }^{89}$ It is safe to say that the creation of the OSDR might contribute to resolving the concerns of potential conflict of interest from an environmental perspective, some concerns may exist considering the OSDR is made up of BEIS staff who are equally concerned with the economic developments. Perhaps these concerns may be allayed by the Oil and Gas Authority's (OGA) assumption of State's resources management role and statutory consultations with other stakeholders. ${ }^{90}$

\subsubsection{Challenges in Regulating Third-Party Access to Infrastructure}

Third-party access to infrastructure is another regulatory challenge that has proven difficult in the UK. The complexity and challenges arise because the regime seeks to maximise economic recovery by relying on new entrants to secure access to infrastructure from unwilling infrastructure owners. The complexity and challenges of this collaborative arrangement are on the basis that "few new discoveries are large enough to

${ }^{87}$ HSE Offshore Safety Directive Regulator <http://www.hse.gov.uk/osdr/authority/index.htm > accessed on the $19^{\text {th }}$ of October 2020.

88 Health and Safety Executive (HSE), 'Offshore Safety Directive Regulator' $<$ http://www.hse.gov.uk/osdr/ $>$ accessed on the $14^{\text {th }}$ of October 2020.

89 Health and Safety Executive, 'The Offshore Installations (Offshore Safety Directive) (Safety Case etc) Regulation 2105: Guidance on Regulation '<http://www.hse.gov.uk/pubns/books/130.htm> accessed on the $14^{\text {th }}$ April 2020.

90 Greg Gordon "Hydrocarbon Policies and Legislation: United Kingdom ” in Eduardo G. Pereira and Henrik Bjornebye (eds), Regulating Offshore Petroleum Resources: The British and Nowegian Models (Edward Elgar 2019) page 170 
justify the creation of an entirely new infrastructure", ${ }^{91}$ while "the efficient use of these existing infrastructure to produce new discoveries will postpone decommissioning". ${ }^{92}$ While this should ordinarily be a win-win for everyone in the sense that there is significant economic justification in the maximisation of economic recovery for both Government and the new entrants (applicants) on the one hand and postponement of decommissioning for the infrastructure owners on the other, there are unresolved competitive interests. ${ }^{93}$ For example, the infrastructure owner may see the applicant as a competitor be it in the UK or other jurisdictions or may rather choose to reserve the ullage for its subsequent use. In all these complexities, it becomes the duty of the Government through its regulator and regulation to play the role of an unbiased umpire. ${ }^{94}$

In regulating TPA, the UK has enacted several regulatory instruments comprising of both hard and soft law. Some of these include the Energy Act 2011, the infrastructure Act 2015, the Maximisation of Economic Recovery Strategy, Code of Practice on Access to Upstream Oil and Gas Infrastructure on the UKCS (ICOP) and the Guidance Note. A combined reading of these instruments and particularly Sections 82 to 91 of the Energy Act 2011 suggests that firstly, applicants and infrastructure owners should independently negotiate and reach an agreement, where they are unable to, the applicant can request the intervention of the Oil and Gas Authority (OGA) to issue an access notice. Such a request will not be

91 Uisdean Vass, 'Access to Infrastructure, in Greg Gordon, John Pater-son and Emre Usenmez (eds), Oil and Gas Law-Current Practice and Emerging Trends: Resource Management and Regulatory Law ( $3^{\text {rd }}$ Edition Edinburgh University Press 2018) 170.

92 Ibid.

93 Abul-Failat Yanal "Third Party Access to Infrastructure in the United Kingdom Continental Shelf: An Unhappy mix of Heavy-Handed Regulation and Light-Handed Regulation" (2014) 12 (1) Oil, Gas and Energy Law Intelligence 2.

94 Alexander Kemp, Euan Phimister and Linda Stephen "Third Party Access to Infrastructure Hubs and the Future Recovery of Oil and Gas Reserves in he UKCS" (2012) British Institute of Energy Economics online at http://www.biee.org/wpcms/wp-content/uploads/Third Party-Access-to-Infrastructure-hubs.pdf accessed 16th January 2020 accessed on the $25^{\text {th }}$ of October 2020. 
granted if the OGA is not convinced that the parties have had a reasonable time to reach an agreement. Furthermore, in reaching a decision and haven listened to all interested parties, it must take into account the capacity that can be reasonably made available; technical incompatibilities which cannot be overcome; difficulties, which cannot reasonably be overcome; the reasonable needs of the owner and his associate; the interest of all users; the need to maintain security and regularity of supplies; and the number of parties. ${ }^{95}$

Despite this perhaps comprehensive regulatory regime, it appeared that there has been some reluctance on the part of the applicant to make an application requesting for an access notice. Some commentators argue that this could be a result of the uniqueness of the oil and gas industry and the idea that a party was in some sense running to the Headmaster especially in an oil industry that prefers to sort things out themselves in a somewhat secretive manner. ${ }^{96}$ To resolve this issue, ICOP requires the applicant to submit an Automatic Referral Notice $(\mathrm{ARN})^{97}$ before the commencement of negotiations so that if an agreement is not reached within six months, the applicant will be committed to approaching the OGA to seek for a Section 82 access notice. Even though the ARN has been in force since 2004, it has not particularly resolved the issue of the "shy applicant"."

The UK TPA regime is both fragmented and one Uisdean Vass describes as a "complex regulatory drama". 99 It is a system that has several interests pulling in sometimes different

95 Section 82(7) Energy Act 2011

96 Abul-Failat Yanal "Third Party Access to Infrastructure in the United Kingdom Continental Shelf: $\mathrm{n}$ Unhappy mix of Heavy-Handed Regulation and Light-Handed Regulation" (2014) 12 (1) Oil, Gas and Energy Law Intelligence 2.

97 Oil and Gas Authority 2Code of Practice on Access to Upstream Oil and Gas Infrastructure on the UK Continental Shelf" (2017) online at https://oilandgasuk.co.uk/wp-content/uploads/2017/08/Infrastructurecode-of-practice-2017.pdf accessed on the $16^{\text {th }}$ of October 2020.

98 Abul-Failat Yanal "Third Party Access to Infrastructure in the United Kingdom Continental Shelf: $\mathrm{n}$ Unhappy mix of Heavy-Handed Regulation and Light-Handed Regulation" (2014) 12 (1) Oil, Gas and Energy Law Intelligence 2.

99 Uisdean Vass, 'Access to Infrastructure, in Greg Gordon, John Paterson and Emre Usenmez (eds), Oil and Gas Law-Current Practice and Emerging Trends: Resource Management and Regulatory Law (3 ${ }^{\text {rd }}$ Edition Edinburgh University Press 2018) 170. 
directions in such a way that it continues to test the limits of regulatory interventions. While the system relies on the negotiation of the parties using the legal instruments as a guide, TPA is one aspect of the UK regulatory regime that confirms the errors of the past in the sense that perhaps if the Government played a more active and central role, it might have resolved these tensions long before now.

\subsubsection{Offshore Decommissioning}

The decommissioning of offshore oil and gas installations continues to test the effectiveness of both the international and UK regulatory framework. In fact, it was erroneous to think that the Brent Spar incident in 1995 had resolved the challenges of offshore decommissioning. With over 6500 offshore oil and gas installations worldwide, 153 in the North Sea and cost implications that continue to rise, the issues of offshore decommissioning are both pertinent and relevant. Recent development surrounding the Brent Delta decommissioning appears to reveal the complex and fragmented nature of the regime.

The Brent Delta platform is equivalent in height to the London Eye and almost the size of a football pitch. In the last 40 years, it has served as a processing plant, a factory, and a hotel to about 160 staff. In a single lift, the topside weighing over 24,000 tonnes was removed in a manner that is described as the world's heaviest offshore lift by a single vessel. ${ }^{100}$ While this is uncontroversial and a remarkable feat that should be commended, unfortunately, the same cannot be said of Shell's decision to leave three out of four of its 300,000 tonnes (each) concrete legs, also known as "Gravity Based Structures" (GBS) on the seabed. ${ }^{101}$ Although Shell claims its decision is a

100 Shell "Decommissioning the Brent Field" online at https://www.shell.co.uk/sustainability/decommissioning/brent-fielddecommissioning/brent-field-downloads/_jcr_content/par/tabbedcontent/tab_863608606/textimage.stream/1459849184730/c8bf39d94a522d1c7f8414383166a99 bce315ae0/decommissioning-the-brent-field.pdf accessed on the $16^{\text {th }}$ of October 2020.

101 Shell U.K Limited "Brent Delta Topside Decommissioning Programme” (2015) Shell Report Number BDE-D-TOP-AA-5880-00001 online at https://assets.publishing.service.gov.uk/government/uploads/sy- 
result of comprehensive assessments and independent review, the German and Dutch Governments, based on commissioned reports, have formally raised objections to Shell's decision. ${ }^{102}$ In an official letter to Michael Gove, the Secretary of State for Environment, Food, and Rural Affairs, the German Government expressed concerns that the decision to leave the concrete-based structures will negatively impact the marine environment, other sea users and therefore, breach the provisions of OSPAR, an international agreement for the protection of the marine environment. In a report by Scientia et Sagacitas an Aberdeen based consultancy commissioned by the German Ministry of Environment, the company highlighted "major issues" with Shell's assessment. The report further "outlined "failures" around environmental assessment, stakeholder engagement and use of outdated technology". ${ }^{103}$

The decommissioning of offshore installations is not exactly a straightforward one and while the rules under OSPAR do appear to take cognisance of these complexities, its application could be quite challenging in some cases. According to OSPAR decision 98/3, "the dumping, and leaving wholly or partly in place, of disused offshore installations is prohibited within the OSPAR maritime area" ${ }^{104}$ However, OSPAR adds that "following assessment, the competent authority of the relevant contracting party may give permission to leave installations or parts of in place if they are steel installations weighing more than 10,000 tonnes in the air, gravity-based concrete structures; floating concrete installations; any concrete anchor-base, which results, or is likely to result, in interference with other legitimate uses of the sea”. 105

stem/uploads/attachment_data/file/441789/Brent_Delta_Topside_DP pdf accessed on the $16^{\text {th }}$ of October 2020.

102 Energy Voice "Germany Makes Formal Objection to Shell's Brent Decommissioning Plans" (2019) online at https://www.energyvoice.com/oilandgas/north-sea/198912/germany-makes-formal-objection toshells-brent-decommissioning-plans/ accessed on the $16^{\text {th }}$ January 2019. See also https://www.energyvoice.com/oilandgas/north sea/209647/netherlands-joins-germany-in-objection-to-shells-brent-decom

103 Ibid. plans/ accessed $16^{\text {th }}$ of October 2020.

104 OSPAR Decision 98/3

105 ibid 
From the above provision, Shell could be within its rights to suggest leaving its gravity-based structures in place but subject to the approval of the competent authority, in this case, the Department for Business Energy and Industry Strategy (BEIS). There is also the requirement to inform other OSPAR Contracting Parties of such a decommissioning plan and it is on this basis that Germany has raised objections. Although this section does not critically examine the details and implications of the offshore oil and gas decommissioning regime and the provisions of OSPAR more specifically, there is a growing body of researchers that appear to question the effectiveness of the regime because is both restrictive and inflexible. ${ }^{106}$ It must also be admitted that designing a robust decommissioning regime that satisfies all stakeholders by balancing energy security, cost, environment, and safety will be a Herculean task, especially under prevailing political and social realities. Regarding the implications of offshore decommissioning in the UKCS, the controversy surrounding the Brent Delta decommissioning has done nothing but test the robustness of regime. Haven said that it is somewhat reassuring that the current regime appears quite sophisticated in the way that it encourages transparency in the decisionmaking process, perhaps in a way that was unavailable two decades ago. While it is expected that there would be a continuous engagement, collaboration and technological advancements that could significantly contribute towards the robustness of the UK off decommissioning regime, experts have suggested that perhaps we may need to provide some clarity regarding the meaning of environmental protection in the context of offshore decommissioning and possible other use for such disused offshore facility. ${ }^{107}$ Particularly in the wake of research suggesting that it may be beneficial to leave offshore installations in the ocean in the well-know rig-to-reef

${ }^{106}$ Ashley Fowler et al "Environmental Benefit of Leaving Offshore Infrastructure in the Ocean" 16(10) The Ecological Society of America 571.

107 John Paterson, "Decommissioning of Offshore Oil and Gas Installations" in Greg Gordon, John Paterson and Emre Usenmez (eds), Oil and Gas Law-Current Practice and Emerging Trends: Resource Management and Regulatory Law ( $3^{\text {rd }}$ Edition Edinburgh University Press 2018) 434. 
practice, which is fairly common in the Gulf of Mexico. ${ }^{108}$ It remains unclear whether that is in the interest of the environment or not. In the wake of these uncertainties, it is evident that there are interesting times ahead for all offshore oil and gas decommissioning. ${ }^{109}$

\subsection{The Norwegian experience}

As with the UK section above, this section examines some of the lessons that can be derived from the Norwegian experience, across four broad themes: political strife and future plans; the regulation of health, safety, and environment; access to infrastructure; and decommissioning. It should not surprise the reader to learn that the Norwegian experience on (and the lessons derived from) each of these fronts is rather different from the UK's, as each issue tends to resonate differently in the Norwegian political context.

\subsubsection{Consensus, fiscal stability, and the future}

Unlike the UK, there has been a broad political consensus in Norway about how the country's petroleum regime should be developed, and for whom it should benefit. This consensus was evident from the start, when the Norwegian parliament agreed, unanimously, to accept the ten Oil Commandments as the strategic framework for developing the sector. These Ten Commandments ensured strong democratic control, a sustained effort to secure local content (including a national oil company), and an early concern that the development of this industry should not be allowed to undermine existing Norwegian industries.

This capacity to pursue a common strategy is part of Norway's political legacy: as a small open economy exposed to world markets, it has always worked to develop common strategies for adapting to these markets (and the institutions

${ }^{108}$ Ann Bull and Milton Love "Worldwide Oil and Gas Platform Decommissioning; A Review of Practices and Reefing Options" (2019) 168 Ocean \& Coastal Management 274.

109 Eduardo G. Pereira, Alexandra Wawryk, Catherine Banet, Heike Trischmann, Keith Hall, Regulation of Decommissioning, Abandonment and Re-Use Initiatives in the Oil and Gas Industry: From Obligation to Opportunities (Kluwer 2020). 
required to secure that adaptation). ${ }^{110}$ But the country also benefited (at first) from the lack of any significant domestic interests based in the petroleum sector. In the late 1960s, the only Norwegian firm with any relationship to the petroleum sector was Norsk Hydro - and its interests were minor (mostly through retail sales). Norsk Hydro's historical roots lay with the fertilizer industry, exploiting Norway's cheap hydroelectric resources, as described above. The Norwegian government enjoyed relatively free reigns when developing the sector, and it could do so in a way that best benefited the Norwegian public, more generally. This freedom came from not having to bow to the pressures of strong and vested commercial interests at home (as they had not yet developed), and the state's willingness to confront powerful foreign interests abroad (once oil was found). This relative autonomy is clearly seen in the government's continued insistence to limit the pace of development - for fear of its effect on the economy (in the form of Dutch Disease), or the environment (e.g. to limit drilling in the environmentally sensitive areas above the $62^{\text {nd }}$ parallel).

The Norwegian political consensus about petroleum policy has also been maintained by an institutional arrangement that helps to ensure that commercial interests cannot capture the regulatory and policymaking channels of the Norwegian government. This is the tripartite institutional structure that is key to the Norwegian model, where:

a) Responsibility for policy lies with the Ministry of Petroleum and Energy (MPE); 111

b) Regulatory responsibility lies with an autonomous Norwegian Petroleum Directorate (NPD), ${ }^{112}$ later complemented by a Petroleum Safety Authority (PSA); ${ }^{113}$ and

${ }^{110}$ See Peter Katzenstein (1985) Small States in World Markets (Ithaca: Cornell University Press).

${ }^{111}$ Government of Norway (n.d.) «Ministry of Petroleum and Energy.» Online at: https://www.regjeringen.no/en/dep/oed/id750/. Accessed on the $1^{\text {st }}$ of October 2020.

112 Norwegian Petroleum Directorate (n.d.) “The North Sea is still viable.” Online at: https://www.npd.no/en/. Accessed on the $1^{\text {st }}$ of October 2020.

113 Petroleum Safety Authority Norway (2020) «Home.» Online at: https://www.ptil.no/en/. Accessed on the $1^{\text {st }}$ of October 2020. 
c) Commercial and operational expertise is housed in the Norwegian NOC, Statoil (now Equinor ${ }^{114}$ ).

This institutional division of labour made it more difficult for a growing commercial concern (e.g. Statoil) to capture and influence the regulatory conditions and/or policy trajectory under which it laboured. This, in itself, is helpful for building consensus around the Norwegian petroleum management strategy.

This talk of consensus does not mean that there have not been significant differences between the left and the right on particular issues related to petroleum. The Labour Party, in general, was far more interested in developing local expertise and content and using the state's power to secure that local content. As the Labour Party was in power during most of the early years of Norway's petroleum adventure, its interests are clearly evident in the country's institutional developments and regulatory trajectory. The Conservative Party (Høyre) tended to embrace a more liberal, free-market, approach to industrial development, but the Conservative Party remained mostly on the electoral sidelines throughout the 1970s and could only affect developments on the margins.

These differences were particularly pronounced on the role of the Norwegian NOC. The Conservatives, when in government, tried to secure a controlling share in Norsk Hydro, rather than start a new NOC from scratch. When the Labour Party took over the government in March of 1971, it abandoned these plans and moved quickly to establish a new firm, Statoil, before showering it with privileges. This allowed Statoil to grow very quickly - in terms of both size and operational experience. As Statoil grew, The Conservative Party began to worry about its influences, and warned that the Norwegian NOC was becoming a "state within a state." This growing concern led to the eventual privatization of Statoil in 1985, and the creation of an institutional firewall between Norway's operational interests (harboured at Statoil) and its financial interests offshore (now housed in another NOC,

${ }^{114}$ Equinor (n.d.) «Home.» Online at: https://www.equinor.com. Accessed on the $1^{\text {st }}$ of October 2020. Likewise, another NOC, Gassco, is responsible for the operation of Norway's extensive natural gas piplines, as described below. The third NOC, Petoro, does not have any operator competencies - its task is limited to financial management. 
Petoro $\left.{ }^{115}\right)$. But even as Statoil has become a private global firm, the Norwegian government retains control over a substantial majority of shares in the company (roughly 67\%). ${ }^{116}$

This consensus over how to manage its offshore petroleum resources was used to secure two types of advantages for the Norwegian people: political and economic. Foreign observers tend to focus on the enormous wealth that Norway has accumulated in its sovereign wealth fund, the GPFG. While this is an important signpost of Norwegian success, it is more interesting to consider how that Fund has been fed, how Norway managed to secure the resource rents from its petroleum resources and used them to benefit the domestic population.

On the economic front, early on, the Norweigan experience was quite different from the British. In Norway, there is little evidence of a "political economy of speed" - quite the opposite! The Norwegian authorities decided to slow the pace of development to ensure that Norwegian firms could participate in the Eldorado (and to deflect Dutch Disease). When it became evident there were viable fields on the NCS, the Norwegian government quickly changed the fiscal terms of trade, and raised tax levels and ownership terms. The radically different terms evident in the first and second allocation rounds are clear evidence of the Norwegian government's capacity to use the Obsolescing Bargaining Mechanism (OBM) to its advantage. ${ }^{117}$ International Oil Companies protested, of course, but they were not scared off: they could still make a great deal of money in the North Sea, and their threats of exit proved hollow. Finally, as the money began to roll in from offshore fields, it was first used to pay down debts, develop national infrastructure and expand social

${ }^{115}$ Petoro (n.d.) “A driving force: offshore Norway.” Online at https://www.petoro.no/home. Accessed on the $30^{\text {th }}$ of September 2020.

116 Equinor (2020) “The Norwegian state as shareholder." Online at: https://www.equinor.com/en/about-us/corporate-governance/thenorwegian-state-as-shareholder.html. Accessed on the $30^{\text {th }}$ of September 2020.

117 See Moses and Letnes, Managing Resource Abundance, pp. 68-70. For background on the OBM, see Vernon, Raymond (1971) Sovereignty at Bay: The Multinational Spread of US Enterprises (New York: Basic Books). 
services: it took a quarter of a century before Norway started saving money in its GPFG.

On the political front, the Norwegian government used its licensing regime to ensure the inclusion and growth of Norwegian expertise. This political favouring is most evident in the growth of Statoil, but Statoil itself was able to use its dominant position to allocate favours to a broader range of Norwegian suppliers. In the early years, Statoil benefited from a licensing regime that: one, secured it major license shares in most allocation rounds; two, ensured its operator status in those licenses (even before many competitors thought it was ready); three, carried its interests; four, granted extra voting rights (enough to commit the license) and five, allowed for a sliding production and rewards scale in the bigger fields. ${ }^{118}$ With Statoil controlling many of the offshore production licenses, it could (and did) help Norwegian firms access the sector and develop their competencies.

Norway's petroleum industry grew up and matured under these sorts of (infant industry) protective policies. Today, Norwegian firms in this industry are active around the world and are seen to be highly competitive internationally. Norwegian policy no longer provides the sort of explicit protections it did in the 1970s (and the international context today makes it much more difficult to pursue these types of policies), but these early protections were essential in the development of her domestic industry and will allow Norwegian firms to continue business (abroad) even after the petroleum is drained from the NCS.

On the other hand, the growth of a strong domestic petroleum sector changed the balance of political power in Norway. As the industry grew, so too did its political influence, and Norwegian governments (on both the left and the right) found it increasingly difficult to pursue policies that would impact negatively on this powerful industry. As a consequence, the consensus that once supported Norwegian policy began to erode, and new cleavages and concerns grew to limit the influence of the petroleum industry on Norwegian policy. The most evident of these new cleavages is the one that separates the country over the future of oil and gas. There is no longer consensus about the role of petroleum in Norway's

${ }^{118}$ See Moses and Letnes, Managing Resource Abundance, p. 157. 
future. We return to this new political cleavage below. The economic gains are clearly evident in the size of the world's largest SWF: the GPFG. Yet, by focusing on the size of this investment fund, we often lose sight of the important instruments by which it was filled. Norway's petroleum fund was not originally formed as a savings account, and it took some time before it began to play that role. Indeed, money began to flow into the Fund only after the Norwegian government had funded more necessary objectives, including paying off its debts and building up the Norwegian welfare state and social services. It took roughly 25 years after the first oil began to be pumped out of the NCS that the first money began to flow into the GPFG.

The original objective of the Fund was to help stabilize the Norwegian economy from the volatile price swings of the oil market, and the threat of Dutch Disease. For this reason, severe constraints were placed on the government's ability to withdraw money from the Fund. Of course, these constraints also helped to grow the Fund quickly, as the Fund's principal remained relatively protected and grew with new payments each year from the petroleum sector.

Many foreign observers do not recognize the source of these deposits into the Fund. To ensure that the oil companies do not abscond with the resource rent (which belongs to the Norwegian people), the Norwegian government employs a very high corporate income tax rate on petroleum producers: roughly 78 per cent (while providing for very generous opportunities for deductions). ${ }^{119}$ These tax revenues constitute the majority of Norwegian petroleum revenues (about $60 \%$ before the 2014 oil price crash). The second-biggest source of petroleum revenues for the Norwegian state comes in the form of the state's direct financial interests in offshore production licenses, the so-called SDFI. In 2013, these licenses generated 36 per cent of the Norwegian government's petroleum revenues. Dividends from the NOC, Statoil, generated a mere four per cent of the state's total petroleum revenues. In 2020, the size and share of these different sources have changed

${ }^{119}$ See Norwegian Petroleum (2020) “The Petroleum Tax System.” 30.09.2020 06:02 draft. Online at: https://www.norskpetroleum.no/en/economy/petroleum-tax/. Accessed on the $30^{\text {th }}$ of September 2020. 
slightly: today, the dividends from Equinor constitutes 15.7 pe cent of the government's petroleum revenues; petroleum taxes generate just 32.5 per cent, while SDFI is the largest source $(42.3 \%)$. The remaining 7.3 per cent are made up of diverse environmental taxes and area fees. ${ }^{120}$

The design of this fiscal regime provides significant stability. This is primarily because the petroleum money is not allowed to enter directly the national economy and government budget: it is funnelled directly to the GPFG, which invests entirely offshore (it is not allowed to invest in Norway). Hence, while most states funnel their petroleum revenues into their government budget, spend accordingly, and then deposit whatever remains in their SWF-the Norwegians keep their petroleum money offshore: they bypass the domestic economy and only allow a small share of the accumulated petroleum revenues to enter the government budget. In particular, the government limits its access to the Fund, by way of an informal agreement (the so-called budgetary rule, or handlingsregel) that allows only three to four per cent of the projected return from the Fund to be transferred to the government budget. This rule ensures that the government receives an even and stable stream of revenue from the Fund (even as petroleum prices remain volatile), while allowing the principal of the Fund to continue growing. ${ }^{121}$

For the most part, the tax regime in Norway has remained remarkably stable. As already noted, the initial radical change in tax and ownership terms (starting with the second allocation round), generated a great deal of concern, opposition and threats to exit (from international oil companies). Since that time, however, the fiscal regime has remained remarkably stable. The international oil companies have accepted the terms offered by the Norwegian government, and have learned to appreciate the stability of the

${ }^{120}$ Revised National Budget, 2020. See Norwegian Petroleum (2020) “T-he Government's Revenues.” 12 May 2020 draft. Online at: https://www.norskpetroleum.no/en/economy/governments-revenues/. Accessed on the $30^{\text {th }}$ of September 2020.

${ }^{121}$ See Moses, Jonathon W. (2020) "Norway's Sovereign Wealth Fund." Forthcoming chapter in Eduardo G. Pereira, Rochelle Spencer and Jonathon W. Moses (eds), Sovereign Wealth Funds, Local Content Policies and CSR: Developments in the Extractives Sector (Springer). 
Norwegian regime and the trust it produces (despite its high costs for these firms).

In the end, the ability of the Norwegian state to secure a financial and operational share of the offshore petroleum activity, and the willingness to secure the resulting rent with a high corporate tax rate, allows a large and steady flow into the Fund, tucked away for future generations.

\subsubsection{Health, Safety and Environment (HSE) Regulation}

The offshore petroleum industry is very lucrative, but it is also very dangerous, complicated and "dirty". From the start, Norwegian policymakers have been aware of the environmental threat posed by drilling for oil in Arctic areas exposed to extremely challenging production conditions. The original ten Oil Commandments included one that would restrict exploration and development above the $62^{\text {nd }}$ degree parallel, out of concerns for environmental sensitivity and the increased challenge of production in ice-filled waters and under harsher weather and surface conditions.

The threat of catastrophe is always present in the petroleum sector, and government officials are in constant need of high-quality, independent expertise to ensure its safe development. As the editors of a recent volume on Risk Governance of Offshore Oil and Gas operations note:

These offshore activities involve sophisticated analytical methods, heavy engineering, large-scale investment, and complex projects, and they must be managed appropriately to ensure that benefits are gained without incurring major accidents and other unacceptable harms to the public, the workers involved, and the human and natural environment. This requires partnerships between public regulators and industry, the involvement of labour and other stakeholders, a supporting role for researchers, mutual trust that best practices will be used and continuously improved, and much more. $^{122}$

${ }^{122}$ Lindøe, Preben Hempel, Michael Baram and Ortwin Renn (eds) (20-14) Risk Governance of Offshore Oil and Gas Operations (New York: Ca mbridge University Press): xv. 
As in the UK, and any other country dealing with the challenges of petroleum extraction, one of the biggest management challenges is to balance the desire to decrease production costs while still protecting worker safety and the environment.

A recognition of this potential conflict of interest lies at the heart of the Norwegian tripartite model, where the authorities hoped to establish an independent source of professional expertise, in the Norwegian Petroleum Directorate (NPD), to counterbalance (and complement) the expert advice coming directly from the industry. Created in 1972, the NPD was first designed to collect, map and process all the information and geological material coming in from the NCS; and to provide policymakers with solid, independent data to inform their policymaking with regard to efficient, but also safe, production. Originally, the NPD was supervised by the Ministry of Industry (where the mining and the nascent petroleum sectors were located), but it enjoyed its own (independent) Board of Directors. Originally, this level of institutional autonomy was thought to suffice.

By the end of the 1970s, however, it became clear that this was not the case: the existing production routines and practices were insufficient. Offshore working conditions were proving to be very dangerous, much more so than in comparable mainland industries. One of the biggest challenges to improving conditions offshore was the reluctance of international oil companies to embrace Norway's corporatist traditions, and the strong role played by unions in developing and managing Norwegian industrial policy. The industry fought hard to keep Norway's onshore unions at bay and was largely successful in this effort before the 1980s.

Two major offshore accidents shook the confidence of Norwegian policymakers and prompted significant reforms in both safety and environmental regulation offshore. First, in 1977, a blowout on the Ekofisk Bravo platform resulted in about 200,000 barrels of oil spilling into the North Sea. ${ }^{123}$ Remarkably, no one died in the incident, but it became evident that the existing management regime was not up to the

${ }^{123}$ See Gjerde, Kristin Øye (2019) “The Bravo Blowout.” Ekofisk Industrial Heritage. 5 November draft. Online at https://ekofisk.industriminne.no/en/the-bravo-blow-out/. Accessed on the $9^{\text {th }}$ of October 2020. 
environmental task at hand. Then, in 1978, the Alexander L. Kielland platform collapsed and sunk, claiming 123 lives. ${ }^{124}$

These two disasters fuelled a critical review of Norwegian safety and environmental regulations and increased public scrutiny on the apparent conflict of interests within the NPD. The public became more critical of the NPD's capacity to promote efficient production while still protecting workers and the environment. These accidents also increased the policy space into which Norwegian labour unions could enter, and their increased influence has had a substantial effect on the nature of Norway's subsequent offshore regulatory regime.

On the regulatory front, responsibilities for the working environment and emergency preparedness were moved from the NPD to the Ministry of Local Government and Labour (and subsequently to the Ministry of Labour, in 2001). In 1994, the NPD was split in two, with the NPD keeping responsibility for regulations that apply to management/efficiency issues, and a new Petroleum Safety Authority (PSA) was made responsible for regulating health and safety issues. ${ }^{125}$ No longer would the NPD report to the Ministry of Petroleum and Energy alone; it would be required now to report to other relevant ministries as well (e.g., Labour and Social Affairs, Climate and Environment ...). Today, much of the heavy regulatory lifting occurs in the Plans for Development and Operation (PDA), which require a description of all relevant aspects related to technical, safety and environmental concerns (along with other areas). ${ }^{126}$

${ }^{124}$ See Officer of the Watch (2013) "Alexander L. Kielladn Paltform Capsize Accident-investigation Report.” 29 April 2013 draft. Online at https://officerofthewatch.com/2013/04/29/alexander-l-kielland plat-form capsize-accident/. Acessed on the $9^{\text {th }}$ of October, 2020.

${ }^{125}$ See the Royal Decree of 17 December 2003, which describes the responsibilities of the NPD and the creation of a new PSA. NPD (2003) "The NPD's responsibilities and tasks." 2 May 2011 draft. Online at. https://www.npd.no/en/facts/news/general-news/2003/The-NPDs-responsibilities-and-tasks-after-separation-of-the-Petroleum-SafetyAuthority-Norway--/. Accessed on the $30^{\text {th }}$ of September 2020. See also Petroleum Safety Authority Norway (2020) "Role and Area of Responsibility.” Online at: https://www.ptil.no/en/about-us/role-andarea-of-responsibility/. Accessed on the $30^{\text {th }}$ of September 2020.

${ }^{126}$ See Petroleum Act of 29 November 1996 no. 79 relating to petroleum activities, as amended: Section 4-2, \$2. Online at https://www.npd.no/en- 
The accident also underscored the need for greater worker voice and influence in the decision-making process offshore. After a series of costly strikes and increased political pressure, the industry slowly acquiesced and began to support the sort of tripartite HSE approaches that dominate in other Norwegian sectors. In particular, the state, industry and workers organizations began to cooperate in discussing, developing and implementing HSE regulations, and eventually (2001) a new management system was introduced that prioritized internal control, operator responsibility and an appropriate HSE culture. This new system shifted responsibility for safety regulation from the state to firms and radically decreased the number of explicit regulations in effect. ${ }^{127}$

The advantages of this new system were highlighted in the wake of the 2010 Macondo disaster in the Gulf of Mexico. Before the accident, US regulations were generally prescriptive with little application of systematic risk management approaches. This stands in stark contrast to Norway's offshore regulations, which are primarily performance-based and supplemented with prescriptive requirements via established norms and standards. After the Macondo disaster, the Norwegian regulatory regime and industry standards were deemed "robust and fit for purpose," ${ }^{128}$ even if a number of specific recommendations were made in a series of post-accident analyses. These include things like updating drilling and well standards; developing

/regulations/acts/act-29-november-1996-no2.-72-relating-to petroleum-activities/. See also Petroleum Regulations No. 653 to the Act relating to petroleum activities of 27 June 1997, as amended: Section 20. Online at https://www.npd.no/en/Regulations/Regulations/Petroleum activities/ accessed on the $25^{\text {th }}$ of October 2020.

127 See Bang, Pauli and Olaf Thuestad (2014) "Government-Enforced SelfRegulation.” In Lindøe et al., Risk Governance, pp. 243-73.

${ }^{128}$ Norwegian Oil Industry Association (n.d.) "Summary report: Deepwater Horizon: Lessons learned and follow up,” p.5. Online at https://www.-norskoljeoggass.no/globalassets/dokumenter/drift/deepwaterho-rizonmacondo/dwh-summary-june-2012.pdf. Accessed on the 30th of September 2020. See also Petroleumstilsynet (2011) «Deepwater Horizon-ulykken: vurderinger og anbefalinger for norsk petroleumsvirksomhet. Hovedrapport). Online at. https://www.ptil.no/contentassets/8c860c31bb6042dca28a99e4b83fef69/dwh_delrapport-1.pdf. Accessed on the 30th of September 2020. 
equipment that can better cap blowouts, and developing better barrier and risk management approaches. ${ }^{129}$

Perhaps the greatest political cleavage in Norway concerns the future of the oil industry as it pushes into more sensitive Arctic waters. As production has increased in size and space, it has increasingly encroached on the fishing industry and some of Norway's most productive fishing grounds. This is a cleavage that sets fishing communities against those that support oil production (and the jobs and revenues it generates). In 2006, the government announced a management plan for drilling in the (northernmost) Barents Sea. Although it eventually banned drilling around some of the country's most productive and sensitive fishing area, e.g. the Lofoten islands), the issue threatens to pop up again in the future. The current government is very responsive to pressure emanating from the petroleum sector, and has agreed to expand drilling in previously untouched areas of the Arctic pushing the boundary of development into the so-called "ice edge". ${ }^{130}$ In the current $\left(25^{\text {th }}\right)$ allocation round, eight of the nine acreages suggested for new oil drilling are in the environmentally-sensitive Barents Sea, while only one area is in the Norwegian Sea. ${ }^{131}$

Hence, as the Norwegian petroleum industry had grown more powerful, and more and more Norwegians rely on that industry for their livelihood, it has become difficult to break the expansion of petroleum into increasingly risky and challenging environments.

${ }^{129}$ Petroleumstilsynet (2020) «10 år sidan Deepwater Horizon.» 20 April $2020 \mathrm{draft}$. Online at https://www.ptil.no/fagstoff/utforskfagstoff/reportasjer/2020/deepwater-horizon-2020/. Accessed on the $30^{\text {th }}$ of September 2020.

130 Nilsen, Thomas (2020) "Norway proposes to open 125 new oil exploration blocks in the Barents Sea." The Barents Observer. 24 June 2020. Online at: https://thebarentsobserver.com/en/industry-and energy/2020/06/norway-proposes-open-125-new-oil-exploration-blocksbarents-sea. Accessed on the $30^{\text {th }}$ of September 2020. See also chapter 14 of the "Jeløya Platform" from 14 January 2018. Online (in Norwegian) at https://www.regjeringen.no/contentassets/e4c3cfd7e $4 \mathrm{~d} 4458 \mathrm{fa} 8 \mathrm{~d} 3 \mathrm{~d} 2$ bb1e43bcbb/plattform.pdf. Accessed on the $30^{\text {th }}$ of September 2020.

131 Norwegian Government (2020) “Høring om 25. konsesjonsrunde.” 24 June 2020 draft. Online at: https://www.regjeringen.no/no/dokumenter/horing-om-25.-konsesjonsrunde/id2715680/. Accessed on the 30th of September 2020. 


\subsubsection{Access to Infrastructure}

The Norwegian authorities have always prioritized the need to maintain public control over the country's petroleum infrastructure. This need was clearly evident in the $6^{\text {th }}$ Oil Commandment, which required that "Petroleum from the NCS must, as a main rule, be landed in Norway." The need and style of government control over infrastructure are particularly evident in its approach to controlling the vast networks of pipelines that service the NCS, and the changes it has needed to ensure that public control.

In the early years of the Norwegian gas adventure, the infrastructure was largely controlled by Statoil, as the state's representative in many of the licenses. In 1983, as part of an attempt to limit Statoil's increased power and influence, the MPE created a "Gas Committee" to coordinate the country's gas activities. Then, in 1985, a Gas Sales Negotiations Committee (Gassforhandlingsutvalget, or GFU) was created to market and sell Norwegian gas. The GFU was made up of Norway's three largest oil companies: Statoil, Norsk Hydro and Saga. All companies producing gas on the NSF were required to use the GFU to market and sell that (Norwegian) gas. ${ }^{132}$

In 2001, this system was undermined by the EU Gas Directive, and Norway was forced to transfer the responsibilities of the GFU over to a new Norwegian NOC, Gassco, which is one hundred per cent owned and controlled by the Norwegian government. ${ }^{133}$ Today, Gassco operates all of Norway's natural gas pipelines (in a joint venture called Gassled) and administers access to an extensive gas delivery regime. In doing so, Gassco ensures third party access on neutral and transparent terms. ${ }^{134}$

With such an extensive gas delivery network already in place, the government has tried to encourage oil companies to exploit it more effectively, allowing better utilization of the underlying resource. To that end, the government introduced

${ }^{132}$ Austvik, Ole Gunnar (2001) «Gassdirektiv, GFU og norske interesser.» Internasjonal politikk 59(3): 367-393.

133 Gassco (2020) «About Gassco.” Online at: https://www.gassco.no/en/about-gassco/. Accessed on the $30^{\text {th }}$ of September 2020.

${ }^{134}$ See Petroleum Act: Section 4-9 and Chapter 9 in the Petroleum Regulations. 
and a new type of concessions system in $2003 .{ }^{135}$ This new system, called "Awards in Predefined Areas (APA), is designed to get more out of the developed areas on the NCS, where the geology is already known, where there are fewer technical challenges, and where it is easy to hook up to already existing infrastructure of pipelines. The objective was to increase the effectiveness and simplicity of the allocation process in more mature areas, to better exploit existing infrastructure and to provide more stability/predictability for firms working in the area. This new allocation system was designed to make it easier for small companies to participate and to allow group application of licenses. ${ }^{136}$ The APA allocations occur annually (traditional concession rounds tend to occur every other year), and more licenses are now allocated through APA schemes than through the traditional concessions scheme. In short, the Norwegian government maintains control over the infrastructure and manages it in a way that is consistent with EU regulations, to ensure neutral access.

\subsubsection{Decommissioning}

In Norway, the issue of decommissioning receives little public attention, in contrast to the very vibrant debate about how (and when) the country will need to transition away from its heavy dependence on petroleum. In contrast to the British case, it is interesting to note the lack of a vibrant political discussion about decommissioning in Norway. We might speculate that there can be two reasons for this. The first reason may be because explicit decommissioning requirements are clearly included in the license requirements issued by the Norwegian authorities. Section 5-3 of the 1996 Petroleum Act required license holders to submit a decommissioning plan to the Ministry of Petroleum and Energy (MPE), within two to five years before a license expires (or the cessation of activities). Retired facilities must

${ }^{135}$ Innst. S. nr. 87 (2002-2003) "Innstilling fra energi- og miljøkomiteen om olje- og gassvirksomheten”. Online at: https://www.stortinget.no/no/Saker-og-publikasjoner/Publikasjoner/Innstillinger/Stortinget/2002 2003/inns-200203-087/. Accessed on the 30th of September 2020.

136 St.meld. nr. 39 (1999-2000) “Olje- og gassvirksomheten.” Oslo: Olje- og energidepartementet. 
be removed in their entirety, and can only be abandoned on the field in very limited cases and after extended use. ${ }^{137}$ In addition, Article 60 of the UN Convention on the Laws of the Sea (UNCLOS) holds that offshore facilities shall, as a rule, be removed. Finally, Norway is a party to the Oslo-Paris (OSPAR) Convention, which contains specific obligations with regard to cessation and decommissioning, including the prohibition of dumping disused offshore installations. ${ }^{138}$

The second reason for a lack of public attention to decommissioning issues in Norway may be the result of its successful efforts at extending the lifetime of its offshore fields, by way of new (APA) concession systems (see above) along with a number of additional incentives. In this way, Norway has been able to postpone the big wave of commissions that will eventually come.

When that happens, the Norwegian parliament can get involved with the decommissioning process under certain conditions. Norwegian regulatory authorities are free to make decisions about the removal of subsea facilities, floating steel facilities and the topsides of concrete installations without submitting their decision to parliament. Yet, if the case involves the disposal of concrete facilities and the jacket on large, fixed steel facilities, then the MPE is expected to consult with the parliament (and OSPAR) before deciding how to proceed. It is important to note that pipelines are not covered by the OSPAR Convention, such that the decommissioning options for pipelines vary by each individual case, based on a comprehensive evaluation, where costs are assessed in relation to the consequences for safety, environment, fisheries and other users of the sea. ${ }^{139}$

${ }^{137}$ Norwegian Petroleum (2020) “Cessation and Decommissioning." $10 \mathrm{Fe}-$ bruary $2020 \mathrm{draft}$. Online at: https://www.norskpetroleum.no/en/developments-and-operations/cessation-and-decommissioning/. Accessed on the $30^{\text {th }}$ of September 2020.

${ }^{138}$ OSPAR Commission. "The Convention for the Protection of the Marine Environment of the North-East Atlantic”, signed 22 September 1992. See https://www.ospar.org/convention accessed on the $25^{\text {th }}$ of October 2020.

139 See Norwegian Petroleum Directorate (n.d.) «Om avslutning av petroleumsvirksomheten og disponering av innretninger.» Online at: https://www.npd.no/globalassets/1-npd/regelverk/avslutning-og-disponeri $\mathrm{ng} / \mathrm{npd}$-om-avslutning-av-petroleumsvirksomheten-og-disponering av-innretninger.pdf. Accessed on the $25^{\text {th }}$ of October 2020. 
The Norwegian authorities think that just under half of the expected recoverable resources on the NCS have been produced, and many of the older facilities are approaching the end of their expected lifetimes. Today there are currently twelve concrete facilities, 20 steel floating facilities and 62 fixed steel facilities in operation (plus 400 subsea installations). To date, the Frigg field has been the largest field decommissioned. Production in this field ceased in 2004, the offshore disposal work started in 2005, and the decommissioning was completed in 2010. The particular date of future decommissioning projects continues to be extended, as new tie-ins (satellite fields) and improved recovery initiatives continue to extend field lifetimes (beyond the original Plan for Development and Operation (PDO) estimates). ${ }^{140}$

More contentious is the decision to continue expanding production on the NCS, even given stringent decommissioning requirements. Norway expects to continue producing significant volumes of oil and gas for decades, even if its younger generations are increasingly vocal in their opposition to these plans. The NPD has argued that it will be possible to maintain production from the [petroleum] sector at a very high level for decades to come and has projected only a slight decline in oil and gas production through to $2040 .{ }^{141}$

It is unclear whether the Norwegian public is willing to support such long-term plans. A recent "Climate Change Report, underscored the vulnerability of the Norwegian economy to a major fall in petroleum prices and activity and emphasized a need to begin transitioning to a post-oil economy. ${ }^{142}$ Norwegian engineering students seem to be

${ }^{140}$ Norwegian Petroleum, op cit.

${ }^{141}$ Down, Adrian and Peter Erikcson (2017) "Norweigan Oil Production and keeping global warming 'well below $2^{\circ} \mathrm{C}$ '.” Energi og Klima. 16 March 2017. https://energiogklima.no/articles-in-english/norwegianoil-production-and-keeping-global-warming-well-below-2c/. Accessed on the 30th of September 2020.

${ }^{142}$ Klimaomstillingsutvalget (2020) «Raskere klimaomstilling. Redusert risiko. Ny politikk for Norge i en verden som når Parismålene.» September 2020. Online at https://www.klimaomstillingsutvalget.no/wp content/uploads/2020/09/Klimaomstillingsutvalgsrapport-2020.pdf. Accessed on the $30^{\text {th }}$ of September 2020. 
boycotting the petroleum trades and seeking out more climate-friendly careers. ${ }^{143}$ And several of the country's political parties are now competing with one another in promising how quickly Norway can transition to a postpetroleum economy.

\section{CONCLUSION}

The above analysis demonstrates that both experiences in the North Sea showed positive and negative lessons in the UK and Norway, despite their remarkably different regulatory governance and management regimes. These experiences could provide useful comparative knowledge for other emerging and/or mature jurisdictions elsewhere in the world. However, it is important to highlight that these experiences evolved over the past decades and were directly related to their political, economic, cultural, and other backgrounds and peculiar characteristics. So a simple "copy and paste" approach (especially in a relatively short timeline) is less likely to work elsewhere. It is suggested that transplanting these approaches will require strategic planning and the requisite political will.

In any case, climate change and energy transition will be significant in defining the future of oil and gas developments and how the industry can achieve more sustainable goals, lower carbon footprint and benefit society as a whole. The key consideration will be how oil/gas-rich countries can strike the appropriate balance between maximising economic recovery of oil and gas resources and making significant contributions to climate goals. Perhaps, the Norwegian initiatives to tax carbon emissions might become more common and countries managing hydrocarbon resources might have to deal with the non-development of certain areas due to higher environmental

${ }^{143}$ We are not aware of any English references to this development. But see Moses and Letnes, Managing Resource Abundance, pp. 220-21, for an overview. See also: Solveig Mikkelsen (2014) "Etisk blikk på oljeforskni ng.” Universitetsavisa.no. January 27. Online at https://www.universite tsavisa.no/forskning/2014/01/27/Etisk-blikk-på-oljeforskning18368873.ece. Accessed on the 8th of October. 2020; NENT (2014)"Vedrørende forskningsetisk vurdering av peroleumsforskning." Case 2014/3. Letter dated June 18. Den nasjonale forskningetiske komite for naturvitenskap og teknologi; and Jeanette Sjøberg (2015) "Studentene vender oljebransjen ryggen.” Aftenposten. 21 May. 
concerns. Nevertheless, oil and gas activities are most likely to remain an important economic, social, and security development for the years to come and so would the quest for a robust regulatory governance regime.

\section{RECOMMENDATIONS}

One important lesson can be devired from the UK experience. While it is difficult to ignore the benefits of oil and gas to the UK economy, the challenges associated with regulating such a complex and fast-evolving industry remains undeniable. The above analysis suggests that perhaps the UK would have benefitted from a more forward-thinking and strategic planning approach and discarded its non-interventionist attitude to petroleum governance. Except for the tax regime which suffered a variety of interventions most approaches were laisser faire. This could have led to a more proactive licensing and regulatory regime that might have avoided or mitigated against some of the regulatory challenges addressed above. Following the uncertainty in the price of oil, the shift towards renewable energy, the economic and political implications of the UK leaving the European Union, the uncertainties of the UK oil and gas industry remain. While the UK did not experience the resource curse in the way many less sophisticated regimes did (i.e. due mostly to its diversified economy), it is hard to ignore the connection between the Scottish call for independence and the desire to control its hydrocarbon resources and the concerns that future generations might have over their natural resources. Perhaps such calls might have been ameliorated by the creation of a sovereign wealth fund like was done in Norway. Although the UK showed a number of lessons learnt about the management of its resources it remains of the few ultra-mature and robust legal regimes in the world.

In addition, two important lessons can be derived from the Norwegian experience. First, many of the benefits Norway derives from its petroleum resources are a consequence of its loud and public recognition that these resources belong to the people of Norway, and the rents that result from these resources also belong with the people. Once a strong democratic foundation was established over the control and ownership of these resources, many of the resulting decisions 
followed easily: it was important to restrict the pace of development, assure national control and develop national competencies, and to ensure that international oil companies did not abscond with the significant rents that resulted. After all, it is these rents that fill the GPFG: now the world's largest sovereign wealth fund. The second lesson is still being contested: the utility of exporting this management model to Norway's other natural resources. Public debate in Norway is now moving beyond oil and gas (even if the petroleum industry drags its feet). But the most important lesson of Norway's management past is not being carried into the future. Norway has had tremendous success in managing its natural resources in the public interest; first with regard to hydroelectric power, then with regard to its petroleum resources. In these sectors, unlike in petroleum, any and all resulting rents are now allowed to fall into private hands. For students of Norwegian petroleum history, it is sad to see this lesson lost on the current and future generations.

Nevertheless, important lessons from both the UK and Norway could be summarised as follows in the importance of:

a) Stragetic and long-term planning.

b) Stability in the regime (especially in the political consensus and fiscal regime).

c) Strong industrial and economic development in other areas related to oil and gas.

d) Educational level in the country, strong legal system, transparency, and low level of corruption, (e) third party access in order to allow higher rates of commercial developments.

e) No signature bonus required in order to increase higher commitments and expendires on exploration work (g) abolishment of royalty as they moved towards mature provinces.

f) Avoid conflict of interest between promoting the sector and dealing with HSE issues under the same "structure".

g) Creation of SWF and diversification of the economy in order to avoid the resource curse.

h) The end of local content policies might have "forced" local companies to be more competitive and international. 